\title{
ECONOMICS OF BIOMASS POWER PLANT
}

\author{
Vladimír GÁLL, Alexander MÉSZÁROS, Ján TKÁČ \\ Department of Eletric Power Engineering, Faculty of Electrical Engineering and Informatics, \\ Technical University of Košice, Letná 9, 04200 Košice, Slovak Republic, tel. +421 55602 4220, e-mail: \\ vladimir.gall@student.tuke.sk, alexander.meszaros@tuke.sk, jan.tkac@tuke.sk
}

\begin{abstract}
This work deals about technology and economics of biomass power plant as renewable source of energy. There is a description of parts of this power plant. In the next part of this work are calculations of annual production costs, unit costs, annual profit and net present value of project. These calculations are solved for three kinds of biomass fuel: vegetable waste, softwood, hardwood and coal as traditional fuel. The amount of investment unit costs for power plants, that use renewable energy sources, will mainly affect the energy density of fuels, resulting specific variable costs.
\end{abstract}

Keywords: biomass, biomass power plant, economic efficiency, renewable resources, fuel, wood, vegetable waste, coal

\section{INTRODUCTION}

Power plants as sources of electricity have significant influence to the economy of the power system. To avoid serious problems in ensuring consistency between the supply of electric energy and the demand for electric energy is necessary to consider various options for development, as sources. The strategic aspect of most countries independence in electric energy production supports the view, that decisive element meet growing electric energy demand remains mainly the construction of new power plants.

In theory regards the optimization of the development of the sources of the electricity power system. To solve this optimization problem, there are several mathematical models most commonly implemented in computer programs. In the expert and lay discussions about the advantages and efficiency of different construction alternatives of electric power plants are often used false arguments in effort to simplify complex problems inadvertently or even intentionally distort the conditions of profitability.

The results are often distorted by inaccurate input data of calculation or misinterpretation of correct calculation results [1] [10] [11] [20] [21].

\section{ECONOMIC EVALUATION OF COSTS OF THE POWER PLANTS}

When choosing a particular design variant of power plant we provided that the annual production cost $N_{p r}$ consist of a fixed component $N_{f i}$ and a variable component $N_{v a}$.

$$
N_{p}=N_{f i}+N_{v a}
$$

Fixed component $N_{f i}$ can be expressed as

$$
N_{f i}=k N_{i}
$$

Investment costs $N_{i}$ can be calculated as

$$
N_{i}={ }_{1} N_{i} P_{m}
$$

Where ${ }_{1} N_{i}$ is investment costs per $1 \mathrm{~kW}$ and $P_{m}$ is installed electric power of power plant. Variable component $N_{v a}$ can be calculated as

$$
N_{v a}=n A=n P_{m} \tau
$$

Where $n$ is specific costs, $A$ is annual production of energy, $P_{m}$ is installed power of power plant and $\tau$ is time of using maximum. The specific costs per unit of the produced energy $n$ of generated electric energy we can calculate as the sum of the specific variable costs $n_{v a}$ and the specific costs of externalities $n_{e x}$.

$$
n=n_{v a}+n_{e x}
$$

We can rewrite equation $N_{p}=N_{f i}+N_{v a}$ (1) and we obtained the dependence of the annual production costs $N_{p r}$ on the annual production of energy $A$.

$$
\begin{aligned}
& N_{p r}=k N_{i}+n A \\
& N_{p r}=k N_{i}+\left(n_{v a}+n_{e x}\right) A \\
& N_{p r}=k_{1}+k_{2} A
\end{aligned}
$$

If annual production costs $N_{p r}$ are divided by annual production of energy $A$, we get equation for specific production costs $n_{p r}$ [5] [6] [15] [16] [25].

$$
\begin{aligned}
& n_{p r}=\frac{k N_{i}}{A}+n \\
& n_{p r}=\frac{k N_{i}}{A}+\left(n_{v a}+n_{e x}\right) \\
& n_{p r}=\frac{k_{1}}{A}+k_{2}
\end{aligned}
$$


If annual production costs $N_{p r}$ are divided by power of plant $P_{m}$, we get equation for specific unit production costs ${ }_{1} N_{p r}$. The equation of all variants we have to divide the same value of power $P_{m}$, otherwise the comparison is not possible. Graphical representation of these specific unit costs ${ }_{1} N_{p r}$ is called the equilibrium diagrams.

$$
\begin{aligned}
& { }_{1} N_{p r}=\frac{k N_{i}}{P_{m}}+n \tau \\
& { }_{1} N_{p r}=\frac{k N_{i}}{P_{m}}+\left(n_{v a}+n_{e x}\right) \tau \\
& { }_{1} N_{p r}=k_{3}+k_{4} \tau
\end{aligned}
$$

If annual production costs $N_{p r}$ are divided by time of using maximum $\tau$, we get equation for production costs per hour ${ }_{l} n_{p r}$.

$$
\begin{aligned}
& { }_{1} n_{p r}=\frac{k N_{i}}{\tau}+n P_{m} \\
& { }_{1} n_{p r}=\frac{k N_{i}}{\tau}+\left(n_{v a}+n_{e x}\right) P_{m} \\
& { }_{1} n_{p r}=k_{5}+k_{6} P_{m}
\end{aligned}
$$

Deciding about the construction of a certain type of power plant brings us many problems connected with the characteristics of individual variants. The proposal is dependent on the annual production of energy $A$, the installed power of the power plant $P_{m}$ and the time of using maximum $\tau$.

\section{ECONOMIC EVALUATION OF PROFITS OF THE POWER PLANTS}

This equation for annual profit $c_{a p}$ considers price of the dispositive electric power $c_{f i}$, price of the consumed electric energy $c_{v a}$, installed power of power plant $P_{m}$, time of using maximum $\tau$, production costs $N_{p r}$.

$$
\begin{gathered}
c_{a p}=c_{f i} P_{m}+c_{v a} A-N_{p r} \\
c_{a p}=c_{f i} P_{m}+c_{v a} P_{m} \tau-N_{p r}
\end{gathered}
$$

The first method calculates values of profit without time factor. Here is a simple equation for the updated profit $c_{\text {wotf }}$ over the lifetime of the device $t$.

$$
c_{\text {wotf }}=c_{a p} t
$$

The total updated profit $C_{\text {wotf }}$ will be

$$
C_{\text {wotf }}=c_{\text {wotf }}-N_{i}
$$

The second method calculates values of profit with time factor. Here is the equation for Net Present Value:

$$
\begin{aligned}
& N P V=\sum_{i=1}^{t} C F_{i}(1+r)^{-t}-N_{i} \\
& q=1+r
\end{aligned}
$$

Where $r$ is interest rate for time and $q$ is factor of time. When all values of annual profits $C F_{i}$ are practically same, we mark them as average annual profits $C F$, and we can rewrite the equation like this.

$$
N P V=C F \sum_{i=1}^{t} q^{-t}-N_{i}
$$

When we mark $N P V$ as $C_{w t f}$ and $C F$ as $c_{a p}$, we can rewrite equation like this.

$$
C_{w t f}=c_{a p} \sum_{i=1}^{t} q^{-t}-N_{i}
$$

Now we can solve and rewrite this equation for total updated profit $C_{w t f}$.

$$
C_{w t f}=c_{a p} \frac{q^{t}-1}{q^{t}(q-1)}-N_{i}
$$

Also we can solve this equation for updated profit $c_{w t f}$.

$$
c_{w t f}=c_{a p} \frac{q^{t}-1}{q^{t}(q-1)}
$$

Here is simple equation for updated profit $c_{w t f}$, total updated profit $C_{w f f}$ and investment costs $N_{i}$ [3] [8] [13] [18] [23].

$$
C_{w t f}=c_{w t f}-N_{i}
$$

\section{DESCRIPTION OF USED TECHNOLOGY}

Most biomass power plants use direct-fired combustion systems. They burn biomass directly to produce highpressure steam that drives a turbine. The turbine drives a generator. The generator produces electricity. In some biomass industries, the extracted or spent steam from the power plant is also used for manufacturing processes or to heat buildings. These combined heat and power systems greatly increase overall energy efficiency to approximately $80 \%$, from the standard biomass electric energy only systems with efficiencies of approximately $20 \%$. Seasonal heating requirements will impact the combined heat and power system efficiency.

A simple biomass electric generation system is made up of several significant components. For a steam cycle, this includes some combination of the following items: fuel stock, handling equipment, furnace, boiler, pumps, fans, steam turbine, generator, condenser, cooling tower, exhaust / emissions controls, system controls (automated). 


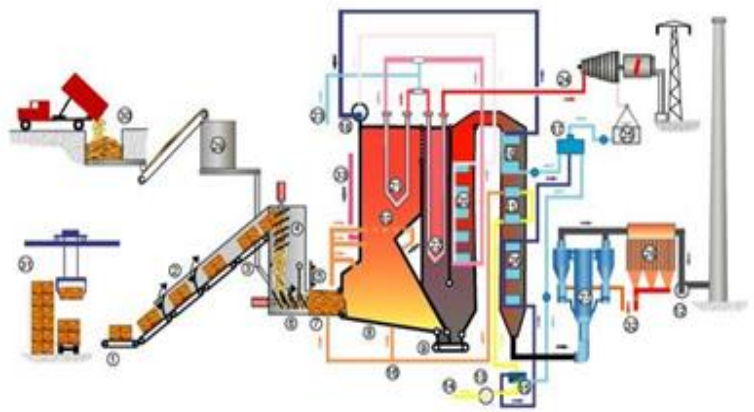

Fig. 1 Figure of power plant

Direct combustion systems feed a biomass feedstock into a combustor or furnace, where the biomass is burned with excess air to heat water in a boiler to create steam. Instead of direct combustion, some developing technologies gasify the biomass to produce a combustible gas, and others produce pyrolysis oils that can be used to replace liquid fuels. Boiler fuel can include wood chips, pellets, sawdust, or bio-oil. Steam from the boiler is then expanded through a steam turbine, which spins to run a generator and produce electric energy. Then is steam condensed in a cooler and goes back to a boiler.

In general, all biomass systems require fuel storage space and some type of fuel handling equipment and controls. A system using wood chips, sawdust, or pellets typically use a bunker or silo for short-term storage and an outside fuel yard for larger storage. An automated control system conveys the fuel from the outside storage area using some combination of cranes, stackers, reclaimers, front-end loaders, belts, augers, and pneumatic transport. Manual equipment, like front loaders, can be used to transfer biomass from the piles to the bunkers, but this method will incur significant cost in labor and equipment operations and maintenance. A less labor-intensive option is to use automated stackers or silo.

Wood thermal power plants typically use one dry kilogram of fuel per one kilowatthour $\mathrm{kWh}$ of electric energy production. This approximation is typical of wet wood systems and it is useful for a first approximation of fuel use and storage requirements, but the actual value will vary with system efficiency.

Most wood chips produced from green lumber will have a moisture content of $40 \%$ to $55 \%$, wet basis, which means that a ton of green fuel will contain $400 \mathrm{~kg}$ to $550 \mathrm{~kg}$ of water. This water will reduce the recoverable energy content of the material, and reduce the efficiency of the boiler, as the water must be evaporated in the first stages of combustion [2] [9] [12] [19] [22].

The biggest problems with biomass-fired plants are in handling and pre-processing the fuel. This is the case with both small grate-fired plants and large suspension-fired plants. Drying the biomass before combusting or gasifying it improves the overall process efficiency, but may not be economically viable in many cases.

Exhaust systems are used to vent combustion byproducts to the environment. Emission controls might include a cyclone or multi-cyclone, a baghouse, or an electrostatic precipitator. The primary function of all of the equipment listed is particulate matter control, and is listed in order of increasing capital cost and effectiveness. Cyclones and multi-cyclones can be used as pre-collectors to remove larger particles upstream of a baghouse like fabric filter or electrostatic precipitator.

In a direct combustion system, biomass is burned in a combustor or furnace to generate hot gas, which is fed into a boiler to generate steam, which is expanded through a steam turbine to produce mechanical energy. The mechanical energy is converted to electric energy in generator [4] [7] [14] [17] [24].

\section{THE COSTS OF BIOMASS POWER PLANT}

For comparison we use power plant with this parameters. Its installed electric power $P_{m}$ is $8,2 \mathrm{MW}$. Time of using maximum $\tau$ is $8000 \mathrm{~h} /$ year. Annual production of electric energy $A$ is $65,6 \mathrm{GWh} /$ year.

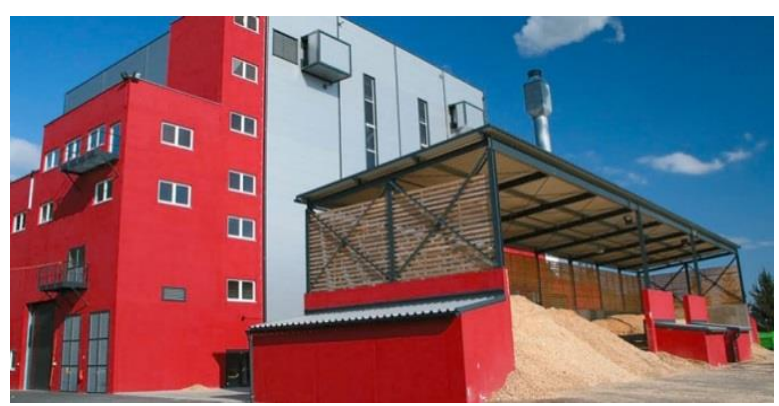

Fig. 2 Biomass power plant in town Bardejov

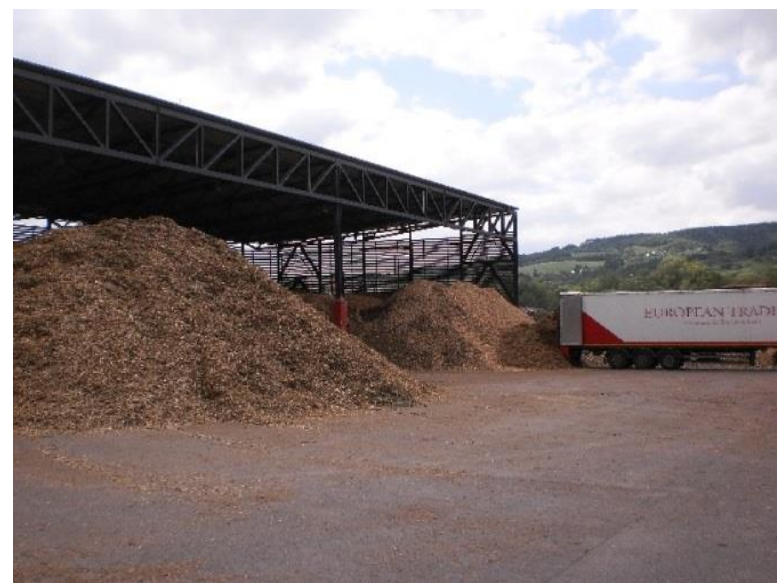

Fig. 3 The stock of biomass and wood

In next table are compared the specific variable cost $n_{v a}$ of three types of biomass fuel and coal as traditional fuel.

Table 1 Specific variable cost $n_{v a}$

\begin{tabular}{|l|l|}
\hline Vegetable waste & $0,054 € / \mathrm{kWh}$ \\
\hline Softwood & $0,061 € / \mathrm{kWh}$ \\
\hline Hardwood & $0,074 € / \mathrm{kWh}$ \\
\hline Coal & $0,079 € / \mathrm{kWh}$ \\
\hline
\end{tabular}

Table 2 Specific variable cost of externalities $n_{e x}$

\begin{tabular}{|l|l|}
\hline Vegetable waste & $0,007 € / \mathrm{kWh}$ \\
\hline Softwood & $0,007 € / \mathrm{kWh}$ \\
\hline Hardwood & $0,007 € / \mathrm{kWh}$ \\
\hline Coal & $0,020 € / \mathrm{kWh}$ \\
\hline
\end{tabular}


The annual production costs $N_{p r}$ for this power plant can be solved by equation $N_{p r}=k_{1}+k_{2} A$

(8). These calculations are shown on the next figure.

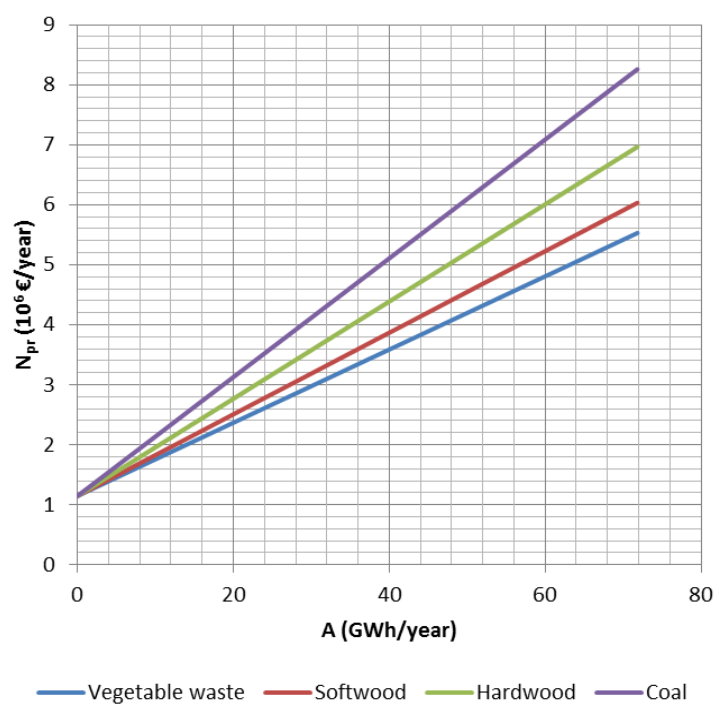

Fig. 4 Annual production costs

The annual production of energy $\mathrm{A}$ is $65,6 \mathrm{GWh} /$ year. Now we can see annual production costs $N_{p r}$ are the highest for coal and the least for vegetable waste.

The specific production $\operatorname{costs} n_{p r}$ for this power plant can be solved by equation $n_{p r}=\frac{k_{1}}{A}+k_{2}$ (11). These calculations are shown on the next figure.

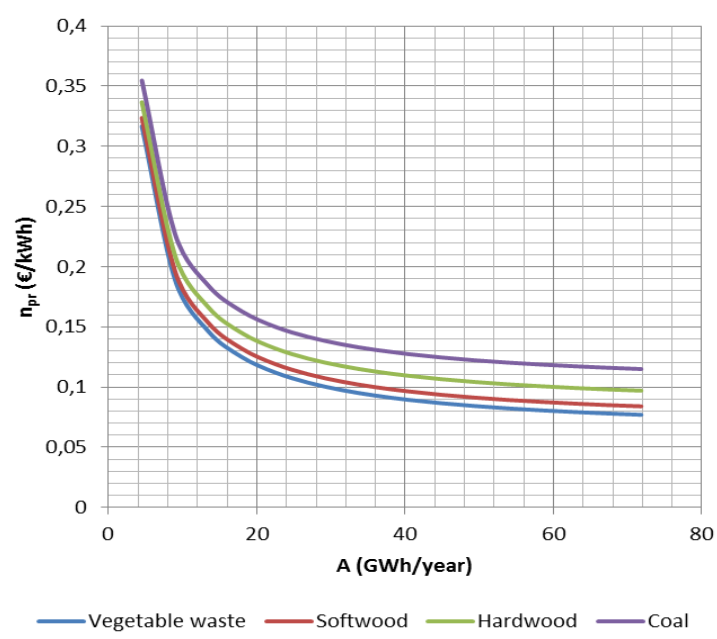

Fig. 5 Unit costs for production of electric energy

The annual production of energy A is $65,6 \mathrm{GWh}$ /year. Now we can see specific production costs $n_{p r}$ are the highest for coal and the least for vegetable waste.

The specific unit production costs ${ }_{i} N_{p r}$ for this power plant can be solved by equation ${ }_{1} N_{p r}=k_{3}+k_{4} \tau$

(14). All variants of fuel were divided with same installed electric power $P_{m}$. These calculations are shown on the next figure. This figure is called equilibrium diagram.

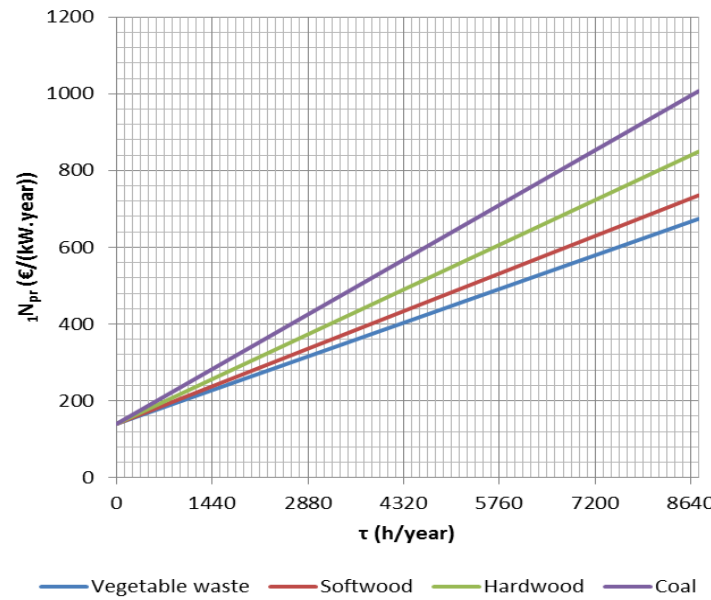

Fig. 6 Equilibrium diagrams

The time of using maximum $\tau$ is $8000 \mathrm{~h} /$ year. Now we can see specific unit production costs ${ }_{1} N_{p r}$ are the highest for coal and the least for vegetable waste.

The hourly costs ${ }_{1} n_{p r}$ for this power plant can be solved by equation ${ }_{1} n_{p r}=k_{5}+k_{6} P_{m}$

(17). These calculations are shown on the next figure.

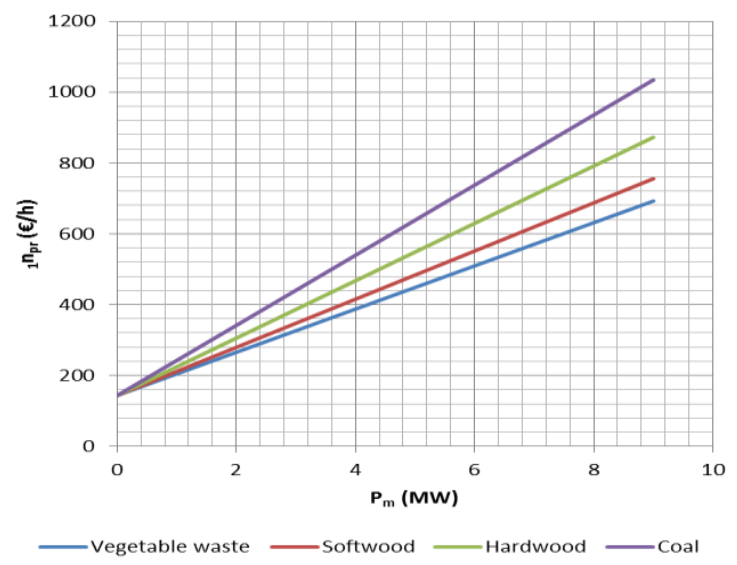

Fig. 7 Hourly costs of production

The installed power of power plant $P_{m}$ is 8,2 MW. Now we can see hourly costs ${ }_{l} n_{p r}$ are the highest for coal and the least for vegetable waste.

The annual profit $c_{a p}$ is calculated by the equation $c_{a p}=c_{f i} P_{m}+c_{v a} P_{m} \tau-N_{p r}$

(19). The annual profit $c_{a p}$ depends on the used fuel. In next table are compared the annual profit $c_{a p}$ of three types of biomass fuel and coal as traditional fuel.

Table 3 Annual profit $c_{a p}$

\begin{tabular}{|l|l|}
\hline Vegetable waste & $4462226,8 € /$ year \\
\hline Softwood & $4003026,8 € /$ year \\
\hline Hardwood & $3150226,8 € /$ year \\
\hline Coal & $1969426,8 € /$ year \\
\hline
\end{tabular}


Than we can calculate updated profit $c_{\text {wotf }}$ by this equation $c_{\text {wotf }}=c_{a p} t$

for first method. If we deduct initial costs $N_{i}$ from updated profit $c_{\text {wotf }}$, we get equation for total updated profit $C_{\text {wotf }}$. The return total updated profit $C_{\text {wotf }}$ is calculated by this equation $C_{\text {wotf }}=c_{\text {wotf }}-N_{i}$

These calculations are shown on the next figure.

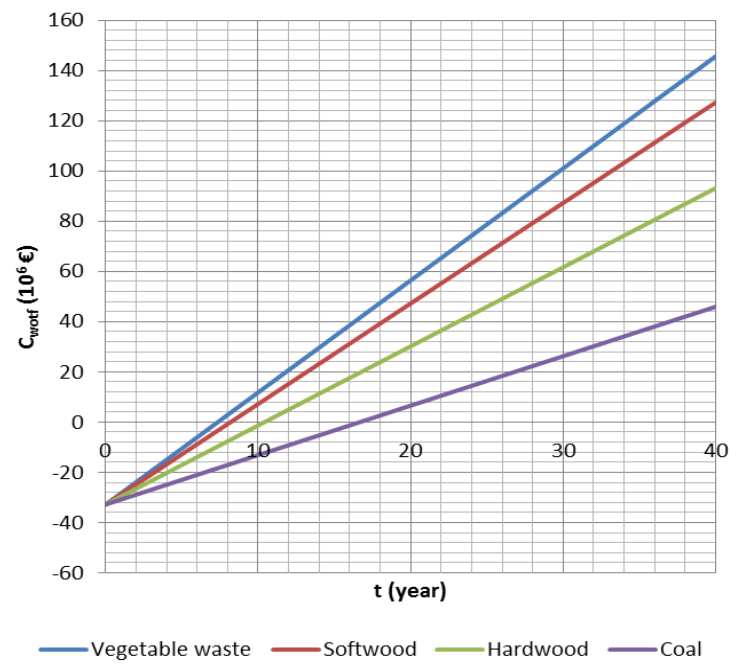

Fig. 8 Return profit without time factor

Than we can calculate updated profit $c_{\text {wotf }}$ by this equation $c_{w t f}=c_{a p} \frac{q^{t}-1}{q^{t}(q-1)}$

for second method If we deduct initial costs $N_{i}$ from updated profit $c_{w t f}$, we get equation for total updated profit $C_{w t f}$. The total updated profit $C_{w t f}$ is calculated by this equation $C_{w t f}=c_{w t f}-N_{i}$

(28).

These calculations are shown on the next figure.

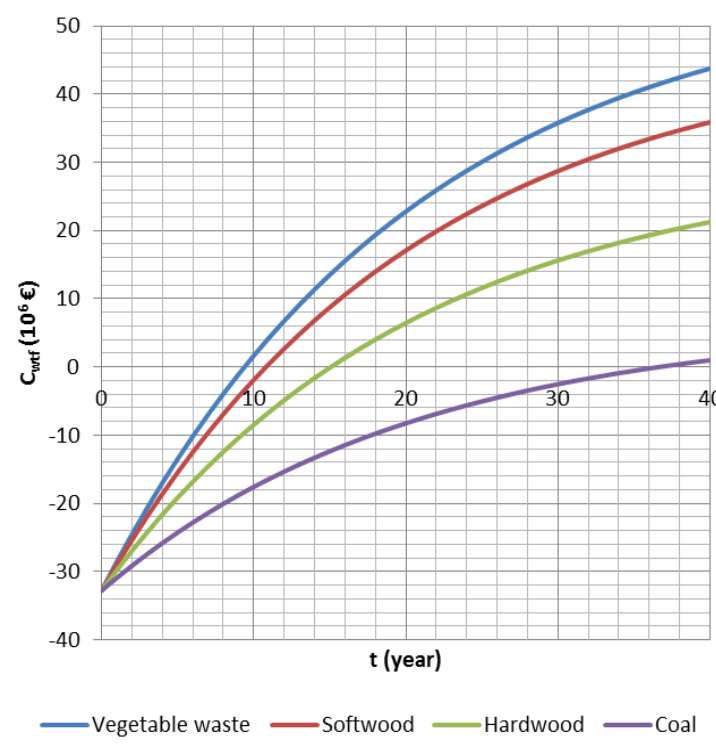

Fig. 9 Return profit with time factor

These calculations are decided for the choose of fuel.

\section{CONCLUSION}

These calculations compare some types of biomass fuel for power plant. The variable costs for biomass fuel are less than for coal. If we calculate total updated profit without time factor, time of return of investment costs is between 7 years and 11 years. If we calculate total updated profit with time factor, time of return of investment costs is between 9 years and 15 years. This solution is economically effective, because there is short time of return of investment costs for biomass fuel. This issue we can see in the last two pictures. As vegetable waste we can use some kinds of grass, hay and straw. As soft wood we can use coniferous wood and wood from bushes. As hard wood we can use deciduous woods. There is comparison between biomass fuel and coal. The variable costs for coal are more than for biomass fuel. Expensive coal, as conventional fuel, is not necessary mined in huge volumes for this power plant. The mining of this fuel causes pollution of environment. This solution is economically less effective, because there is longer time of return of investment costs for coal. If we calculate total updated profit without time factor, time of return of investment costs is 17 years. If we calculate total updated profit with time factor, time of return of investment costs is 37 years. The future problems with fossil fuels can be solved. Currently, these calculations simulate results only for biomass power plant. But many types of power plants were invited. For the future calculations can be compared with other types of power plants.

\section{ACKNOWLEDGMENT}

This work was supported by the Scientific Grant Agency of the Ministry of Education of Slovak Republic and the Slovak Academy of Sciences under the contract No. Vega 1/0388/13.

\section{REFERENCES}

[1] KOLCUN, M. - BEŇA, L'. - MÉSZÁROS, A.: 'Optimalizácia prevádzky elektrizačnej sústavy', Technical University of Košice, 2009, ISBN 978-80553-0323-9

[2] KOLCUN, M. - CHLADNÝ, V. - MEŠTER, M. CIMBALA, R. - TKÁČ, J. - HVIZDOŠ, M. RUSNÁK, J.: 'Elektrárne', Technical University of Košice, 2006, ISBN 80-8073-704-5

[3] DORF, C. R.: 'Energy, resources and policy', Addinson Wesley Publishing Company Inc., 1978, ISBN 0-201-01673-7

[4] KOLCUN, M. - GRIGER, V. - BEŇA, L. RUSNÁK, J.: 'Prevádzka elektrizačnej sústavy', Technical University of Košice, 2007, ISBN 978-808073-897-2

[5] NOVÁK, P.: 'Elektrické teplo', Technical University of Košice, 2010, ISBN 978-80-89284-48-1

[6] VARGA, L. - ILENIN S. - LEŠČINSKÝ P., 'Prenos a rozvod elektrickej energie', Technical University of Košice, 2003 
[7] CHLEBNÝ, J. - BENEŠ, P. - LANGER, J. - KRÁL, J. - MARTINÁSKOVÁ, M.: 'Automatizace a automatizační technika', Computer Press Brno, 2014

[8] JARET, P.: 'Electricity for Increasing energy efficiency', John Wiley \& Sons, 1992

[9] KHATIB, H.: 'Economics of reliability in electrical power systems', Technicopy, 1978

[10] KHATIB, H. - MUNASINGHE, M.: 'Electricity, the environment and sustainable world development', World Energy Council 15th congress, Madrid, September 1992

[11] NAKICENOVIC, GRUBLER, and MCDONALD: 'Global Energy Perspectives' (Cambridge University Press, 1998)

[12] MUNASINGHE, M.: 'Energy Analysis and Policy' (Butterworth, London, 1990)

[13] MINCHENER, A.: 'Coal comes clean', IEEE Rev. Nov./Dec. 1991, 3711

[14] SIMON, M.: 'The road to environmentally compatible power and heat generation', ABB Rev., 3, (91)

[15] BLARK - VEATCH: 'An Attractive Option', Electricity International, May 2002, pp 26-28

[16] BOURDAIRE, J.-M.: 'The link between GNP and energy consumption', Oxford Energy Forum, May 1995,21

[17] KHATIB, H.: 'Electricity in the global energy scene', IEEE Proc. A, June 1993, 140, (1)

[18] ARGIRI, M. BIROL, F.: 'Renewable Energy', Oxford Energy Forum, Issue 49, May 2002, pp 3-5

[19] BREEZE, P.: 'Power generation Technologies - First edition' Published by Elsevier, 2005

[20] BREEZE, P.: 'Power generation Technologies Second edition' Published by Elsevier, 2014

[21] VAN SWAAIJ, W. - KERSTEN, S. - PALZ, W.: 'Biomass Power for the World' CRC Press Taylor and Francis Group LLC, 2015
[22] BIZON, N. - SHAYEGHI, H. - TABATABAEI, N. M.: 'Analysis, Control and Optimal Operations in Hybrid Power Systems' Springer-Verlag London 2013, ISBN 978-1-4471-5538-6

[23] MASTERS G. M.: 'Renewable and Efficient Electric Power Systems' Published bz John Wiley and Sons, New Jersey, 2004, ISBN 0-471-28060-7

[24] YUANCHUN, S.: 'Biomass to Win the Future' Published by Lexington Books, United Kingdom, 2014, ISBN 978-0-7391-7372-5

Received July 17, 2015, accepted October 13, 2015

\section{BIOGRAPHIES}

Vladimír Gáll was born in Kojatice, in 1988. He received the MSc. degree from Faculty of Electrical Engineering, Technical University of Košice in 2013.

Alexander Mészáros was born in Rožňava, in 1959. He received the MSc. degree from Faculty of Electrical Engineering, Technical University of Košice in 1983, and the PhD. degree from Faculty of Electrical Engineering, Technical University of Košice in 2002. Since 1996 he has been working at the Department of Electric Power Engineering, Faculty of Electrical Engineering, Technical University of Košice as an assistant professor, since 2009 as an associate professor. His major fields of interests are economic and environmental aspects of electric power systems.

Ján Tkáč was born in Košice, in 1953. He received the MSc. degree from Faculty of Electrical Engineering, Technical University of Košice in 1976, and the CSc. degree from Faculty of Electrical Engineering, Slovak Technical University Bratislava in 1986. Since 1977 he has been working at Research and Development Base of East Slovak Power Plants. Since 1977 he has been working in the Department of Electric Power Engineering, Faculty of Electrical Engineering, Technical University of Košice as an assistant professor. His major fields of interests are renewable energy sources and environmental aspects of electric power systems. 